\title{
Demographic and Family Related Barriers on Women Managers' Career Development
}

\author{
Indra Devi Subramaniam ${ }^{1}$, Tanusia Arumugam ${ }^{1} \&$ Abu Baker Almintisir Abu Baker Akeel ${ }^{1}$ \\ ${ }^{1}$ Graduate School of Management, Multimedia University, Cyberjaya, Malaysia \\ Correspondence: Indra Devi Subramaniam, Graduate School of Management, Jalan Multimedia, 63100 \\ Cyberjaya, Malaysia. Tel: 60-3-8312-5716. E-mail: indra@mmu.edu.my
}

Received: July 31, 2013 Accepted: November 6, 2013 Online Published: December 31, 2013

doi:10.5539/ass.v10n1p86

URL: http://dx.doi.org/10.5539/ass.v10n1p86

\begin{abstract}
The purpose of this study was to examine the influence of demographic variables and family related barriers on women managers' career development in government-linked companies in Malaysia. A theoretical framework was developed based on review of literature and two main hypotheses and five sub-hypotheses were proposed to be tested. A correlation study was used in this study based on quantitative research approach. A structured questionnaire was used to collect data. A sample of 466 of women managers collected from Malaysian government-linked companies. The results showed that job level, age, marital status, highest education qualification and family related barriers have significant relationship with women managers' career development.
\end{abstract}

Keywords: women managers' career development, demographic variables, family related barriers, Malaysian GLCs

\section{Introduction}

The total number of women in administrative and managerial positions has increased over the years; however the proportion of women moving to top leadership positions still remains low. Research from Grant Thornton International Business Report (2012) revealed that only $21 \%$ of senior management roles are globally held by women which cover both listed and privately held business. Therefore, it is important to understand why women are underrepresented in top leadership positions in their companies. It is noted that the highest obstacles women in leadership positions face is gender stereotyping where the policy 'manager equals male' exists (Hoobler, Wayne \& Lemmon, 2009). According to Lyness and Heilman, the contrast between both genders are extremely large where women are referred as generous and caring while men are believed to be strong in dealing with situations and capable in achieving their goals (Lyness \& Heilman, 2009). Two potential barriers identified for women's lack of career development and academic achievements are family obligations and reproductive roles (Wolfinger, Mason \& Goulden, 2008). According to Harvey (2007), the stimulation of women leadership roles and aspirations will be critical in their career development. In some research, women agree that taking time off to have children and child bearing responsibilities inhibit their career development (Shanon, 2007). Empirical research found that there is negative relationship between work-family conflict and career leadership development (Javeri \& Dariapour, 2008). In other evidence, family support has direct relationship between both family-work and work-family enrichment (Baral \& Bhargava, 2011), job satisfaction and organizational commitment (Marcinkus et al., 2007). A research study by Cross (2010) found that childbearing year is a significant barrier to the majority of women managers. In Ireland, women can have 42 weeks of maternity leave and however those who take up this benefit are less likely to be promoted. Therefore, the dilemma for most women in leadership position is whether to have children or they have to choose between career and family.

\section{Review of Literature}

\subsection{Demographic Variables and Women Managers' Career Development}

Wentling (2003) showed that development of women to top managerial positions depends on their education and the development opportunities. A study conducted by Metz (2005), it is found that when women increases their education, it might help them to breakdown the glass ceiling in the organization. Broadbridge (2007) studied about the contributors and obstacles toward executive career for both male and women employees. In this study 
women cited demographic characteristics as definite obstacles towards career development. In addition, they reported that family responsibilities in the form responsibility for their household and child care as further barriers towards their career progression. This occurred in spite of there not being important differences in men and women's educational achievements. Other reason cited by the women was that there was lack of facilities to help them to combine their home and work responsibilities. Theory by Levinson (1978) found that there are different timetable for women in reaching certain level in organization by certain age and these does not accurately define the careers of most women. In survey conducted by Levinson (1996) on females between ages of 35 and 45 found that women faces 'gender splitting' in throughout their career. In addition, by age 30, women may change their focus on either career or family or vice versa (Roberts \& Newton, 1987).

Metz (2005) who surveyed women with and without children and their job development found that, although the links and barriers to the advancement of mothers and non-mothers are similar, important differences exist. More specifically, the study found that internal networks are negatively related to the advancement of women with children, but was unrelated to the advancement of women without children. Having children was found to weaken the relationship between work hours and managerial advancement. Past studies have shown that many of the women managers and executives are married, but do not have children because of work commitments (Catalyst, 2003). Furthermore, Tharenou (1997) reviewed the literature and mentioned that ambition is associated with women's managerial development. Brett and Stroh (1999) found out that among women singles, women with children, and women married without dependents, the job experiences are similar but women having kids had less working hours and training and development (Liff \& Ward, 2001).

On the basis of the literature review, the following hypotheses are proposed:

H1: Women managers' demographic variables is significantly related to their career development

H1a: Women managers' job level is significantly related to their career development

H1b: Women managers' age is significantly related to their career development

H1c: Women managers' marital status is significantly related to their career development

H1d: Women managers' highest education qualification is significantly related to their career development

H1e: Women managers' number of children is significantly related to their career development

\subsection{Family Related Barriers and Women Managers' Career Development}

Family responsibilities have also been considered in the context of women's career development (Lirio et al., 2007), particularly with relation to marital status and child care (Davidson \& Burke, 2004). An important aspect in the context of women's career development is family responsibilities which related to marital status and child care (Davidson \& Burke, 2004). A number of studies have indicated that combining a family and career can hinder a women's career development. Studies have shown that in the West, women managers have to make difficult choices, such as remaining single or childless in comparison to their male counterparts, who, in the majority of cases, are married with children (Powell \& Graves, 2003). In some cases, women remain the primary caregiver with added responsibility of household organization (Lopez - Claros \& Zahidi, 2005). In dual income households, where both share the family responsibilities, the ideal role arrangement still targets women with additional responsibilities (Budworth, Enns \& Rowbotham, 2008). According to Tharenou (2005), lack of adequate childcare has been a barrier to women managers and threatens their career advancement. Women may be at disadvantage in terms of family responsibility where high commitments to organization are expected (Mavin, 2001). Besides, organization look less favorable on married women when comes to promotion compared to those who are single (Kelly \& Marin, 1998).

On the basis of the literature review's finding, this hypothesis is proposed:

H2: Family related barriers is significantly related to women managers' career development to top management position.

\section{Methodology}

This is essentially a correlation study that uses quantitative approach and uses the survey method to collect data. The independent variables are the demographic variables and family related barriers. The dependent variable is women managers' career development. A structured questionnaire is used in this study. The target population was women managers working in Malaysian Government -Linked Companies (GLCs). A convenience sampling technique was used as only those who consented to participate in the study were selected as respondents. The primary data are data gathered and assembled through questionnaire, which requires asking women managers' in GLCs (who are called respondents) for information. A total of 466 completed questionnaires were collected in 
this study. Secondary data was mostly collected from journal articles, Internet newspaper articles and textbooks.

\section{Results}

Table 1 to Table 9 describes demographic characteristics of the respondents in this study including job level, age, and marital status, number of children, education qualification, and working experience as important factors in career development, responsibility in looking after children, responsibility in running the household and other family responsibilities.

Table 1. Distribution of the respondents according to job level

\begin{tabular}{llcc}
\hline & Frequency & Percentage \\
\hline Senior Manager & 88 & 19.0 \\
Middle Manager & 162 & 34.9 \\
Line Manager & 212 & 45.7 \\
Others & 2 & 0.4 \\
Total & 466 & 100.0 \\
\hline
\end{tabular}

The main responses are in the job level of line managers with a percentage of $45.7 \%$. About $35 \%$ are middle managers and $19 \%$ are senior managers. A line manager, sometimes called a direct manager, is a person who directly manages other employees and is responsible for the administrative management of the individual as well as the functional management.

Table 2. Distribution of the respondents according to age

\begin{tabular}{cccc}
\hline & Frequency & Percentage \\
\hline $26-30$ & 55 & 11.8 \\
$31-35$ & 153 & 32.8 \\
$36-40$ & 114 & 24.5 \\
$41-45$ & 87 & 18.7 \\
$46-50$ & 46 & 9.9 \\
$>50$ & 11 & 2.4 \\
Total & 466 & 100.0 \\
\hline
\end{tabular}

The distribution of the respondents according to their age group is presented in Table $2.12 .2 \%$ of respondent are below 31 years old; $33 \%$ of respondents are between $31-35$ years old; $24.2 \%$ of respondents are between $36-40$ years old; $18 \%$ of respondents are between $41-45$ years old; $10.1 \%$ of respondents are between $46-50$ years old and only $2.4 \%$ of respondents are above 50 years old. Mean age of respondents in this study is 31-35 years old.

Table 3. Distribution of respondents according to marital status

\begin{tabular}{llcc}
\hline & Frequency & Percentage \\
\hline Single & 133 & 28.5 \\
Married & 327 & 70.2 \\
Divorced & 6 & 1.3 \\
Total & 466 & 100.0 \\
\hline
\end{tabular}

The distribution of respondents according to their marital status is presented in Table 3. From the Table 3, we found that most of the respondents are married which contributes $70.2 \%$, while $28.5 \%$ and $1.3 \%$ are still single and divorced respectively. 
Table 4. Distribution of respondents according to highest education qualification

\begin{tabular}{lcc}
\hline & Frequency & Percentage \\
\hline PhD & 18 & 3.9 \\
Master & 245 & 53.7 \\
Bachelor's Degree & 187 & 41.0 \\
Diploma & 6 & 1.3 \\
Total & 456 & 100.0 \\
\hline
\end{tabular}

According to Table 4, there is no senior manager, middle manager or even line manager with under diploma educational level. This table shows that majority of the respondents, $53.7 \%$ have obtained master degree. $41 \%$ have bachelor degree proving that women managers' are highly educated. There is $3.9 \%$ having doctorate degree from middle and senior managers' and the least $1.3 \%$ of respondents have diploma degree.

Table 5. Distribution of respondents according to the number of dependent children

\begin{tabular}{llcc}
\hline & Frequency & Percentage \\
\hline None & 148 & 32.0 \\
One & 112 & 24.2 \\
Two & 124 & 26.8 \\
Three & 38 & 8.2 \\
Four & 27 & 5.8 \\
Five & 7 & 1.5 \\
PFive & 7 & 1.5 \\
Total & 463 & 100.0 \\
\hline
\end{tabular}

According to Table 5, the women managers in senior, middle and line manager range from none to more than five children. In this study, $32 \%$ of the respondents have no dependent children; $24.2 \%$ have 1 dependent child; $26.8 \%$ have 2 dependent children; $8.2 \%$ have 3 dependent children; $5.8 \%$ have 4 dependent children; $1.5 \%$ has 5 dependent children and only $1.5 \%$ has more than 5 children.

Table 6. Distribution of respondents according to the most important factor in career development

\begin{tabular}{lcc}
\hline & Frequency & Percentage \\
\hline Job Experience & 163 & 35.0 \\
Educational Progression & 36 & 7.7 \\
Job Performance and Competence & 267 & 57.3 \\
Total & 466 & 100.0 \\
\hline
\end{tabular}

From Table 6 , it can be concluded $57.3 \%$ of all participants believe that their individual capabilities which are job performance and competence are an important factor in their career development followed by job experience $(35 \%)$ and educational advancement $(7.7 \%)$. 
Table 7. Distribution of respondents' responsibilities: looking after children

\begin{tabular}{lrrrr}
\hline & Frequency & Percentage & Valid Percentage Cumulative Percentage \\
\hline Myself & 30 & 9.2 & 9.2 & 9.2 \\
My husband & 11 & 3.4 & 3.4 & 12.5 \\
My husband and I share the & 172 & 52.6 & 52.6 & 65.1 \\
responsibility & & & & \\
My Parents/ In Laws & 73 & 22.3 & 22.3 & 87.5 \\
Maid & 41 & 12.5 & 12.5 & 100.0 \\
Total & 327 & 100.0 & 100.0 & \\
\hline
\end{tabular}

The distribution of the respondents according to their responsibility in looking after children is presented in Table 7. 9.2\% of respondents are looking after their child or children by themselves; $3.4 \%$ by their husband; majority $52.6 \%$ by both husband and wife; $22.3 \%$ by parents or in laws and $12.5 \%$ by maid.

Table 8. Distribution of respondents' responsibilities: running the household

\begin{tabular}{lrccr}
\hline & Frequency & Percentage & Valid Percentage Cumulative Percentage \\
\hline My self & 54 & 16.5 & 16.5 & 16.5 \\
My husband & 44 & 13.5 & 13.5 & 30.0 \\
My husband and I share the & 187 & 57.2 & 57.2 & 87.2 \\
responsibility & & & & \\
Myself with the help of the maid & 14 & 4.3 & 4.3 & 100.0 \\
Myself with the help of parents / In & 28 & 8.6 & 8.6 & \\
laws & & & & \\
Total & 327 & 100.0 & 100.0 & \\
\hline
\end{tabular}

The distribution of the respondents according to their responsibility in running the household is presented in Table $8.16 .5 \%$ of respondents are running the household by themselves; $13.5 \%$ by their husband; majority $57.2 \%$ by both husband and wife; $8.6 \%$ by themselves with the help of parents or in laws and $4.3 \%$ by themselves with the help of maid.

Table 9. Distribution of respondents' responsibilities: other family responsibility

\begin{tabular}{lrrrr}
\hline & Frequency & Percentage & Valid Percentage & Cumulative Percentage \\
\hline Aged parents/ In laws & 139 & 42.5 & 51.1 & 51.1 \\
Sick parents/ In Laws & 52 & 15.9 & 19.1 & 70.2 \\
Siblings & 31 & 9.5 & 11.4 & 81.6 \\
None & 50 & 15.3 & 18.4 & 100.0 \\
Total & 272 & 83.2 & 100.0 & \\
\hline
\end{tabular}

The distribution of the respondents according to looking after other family responsibilities is presented in Table 9. Majority $51.1 \%$ of respondents are looking after their aged parents or in laws; $19.1 \%$ looking after sick parents or in laws; $11.4 \%$ are looking after their siblings and only $18.4 \%$ are free from additional responsibilities. 
Table 10. Descriptive statistic: family responsibilities as barriers

\begin{tabular}{lccc}
\hline Family Responsibilities as Barriers & N & Mean & $\begin{array}{c}\text { Std. } \\
\text { Deviation }\end{array}$ \\
\hline $\begin{array}{l}\text { Marriage, commitment, bringing up children and taking care of old parents has } \\
\text { acted as impediment to my job advancement }\end{array}$ & 453 & 2.64 & 1.129 \\
$\begin{array}{l}\text { Maintaining balance between managing family affairs and job responsibilities is } \\
\text { difficult task }\end{array}$ & 451 & 2.33 & 0.987 \\
$\begin{array}{l}\text { I feel guilty if I do not spend enough time with my children } \\
\text { My priority is my job and I am prepared to neglect my family responsibilities to } \\
\text { advance in my job ( R) }\end{array}$ & 444 & 2.25 & 0.863 \\
$\begin{array}{l}\text { I think that over time and more job responsibilities will have a bad effect on my } \\
\text { family life }\end{array}$ & 444 & 2.78 & 0.746 \\
$\begin{array}{l}\text { A female manager holding a senior position can be a considerate mother and } \\
\text { diligent manager simultaneously ( R) }\end{array}$ & 446 & 2.10 & 0.892 \\
$\begin{array}{l}\text { If I did not enjoy my husband's assistance in housework, I would not be able to } \\
\text { accept a managerial position }\end{array}$ & 444 & 2.57 & 0.892 \\
$\begin{array}{l}\text { My commitment to my family life, my children or my parents is a barrier for my } \\
\text { career advancement }\end{array}$ & 445 & 2.96 & 0.920 \\
$\begin{array}{l}\text { If I was not married and I did not have any commitment to my family members, I } \\
\text { would have gotten a higher managerial position }\end{array}$ & 451 & 2.90 & 0.794 \\
$\begin{array}{l}\text { At first a woman should be a considerate mother and wife rather than a successful } \\
\text { manager }\end{array}$ & 455 & 3.22 & 0.950 \\
\begin{tabular}{l} 
Overall Mean \\
\hline
\end{tabular} & 455 & 2.72 & 0.535 \\
\hline
\end{tabular}

Table 10 presents the respondents' perception regarding family responsibilities as barriers to women managers' career development. Since the response was measured using a Likert scale ranging from 1 to 5 , the average value for the scale is 2.5 . The mean value for the respondents' perception of family related barriers is 2.72 with the standard deviation of 0.535 . This suggests that majority of the respondents moderately agreed that family responsibilities serve as a barrier to their career development.

Table 11. One-way ANOVA for demographic variables and women managers' career development

\begin{tabular}{llcccc}
\hline Demographic Variables & & Df & Mean Square & F & Sig. \\
\hline Job Level & Between Groups & 19 & 1.313 & 2.353 & .001 \\
& Within Groups & 444 & .558 & & \\
& Total & 463 & & & \\
Age & Between Groups & 19 & 5.177 & 3.613 & .000 \\
& Within Groups & 446 & 1.433 & & \\
& Total & 465 & & & \\
Marital Status & Between Groups & 19 & .607 & 2.918 & .000 \\
& Within Groups & 446 & .208 & & \\
Highest Educational Qualification & Total & 465 & & & \\
& Between Groups & 19 & .880 & 2.733 & .000 \\
& Within Groups & 436 & .322 & & \\
Tumber of Children & Total & 455 & & & \\
& Between Groups & 19 & 6.905 & & \\
& Within Groups & 443 & 1.946 & & \\
& Total & 462 & & & \\
\hline
\end{tabular}


The result of relationship between demographic variables (job level, age, and marital status, number of children, educational qualification and important factor in career development) and women managers' career development analysed using a one-way ANOVA is presented in Table 11. The results in Table 11 allow for making a decision regarding hypotheses $\mathrm{Hla}, \mathrm{H} 1 \mathrm{~b}, \mathrm{H} 1 \mathrm{c}, \mathrm{H} 1 \mathrm{~d}$ and $\mathrm{H} 1 \mathrm{e}$.

Therefore, the results from one-way ANOVA analysis in Table 11, show that there is significant relationship between job level and women managers' career development $\left(F_{(19,444)}=2.353, p<0.05\right)$. Scheffe's test of multiple comparisons was not conclusive. Age was found to be significantly related to women managers' career development $\left(\mathrm{F}_{(19,446)}=3.613, \mathrm{p}<0.05\right)$. Scheffe's test of multiple comparison found that there was significant difference in career development for women between the ages of 26-30 with 31-35 and between 26-30 and 36-40 years. Marital status was found to be significantly related to women managers' career development $\left(\mathrm{F}_{(19,446)}=\right.$ 2.918, $\mathrm{p}<0.05$ ). Highest Educational Qualification was found to be significantly related to women managers' career development $\left(\mathrm{F}_{(19,436)}=2.733, \mathrm{p}<0.05\right)$. Scheffe's test of multiple comparisons found that there was significant difference in career development for women between the educational qualification of $\mathrm{PhD}$ with Master and between PhD and Bachelor' Degree. Number of children was found to be not significant related to women managers' career development $\left(\mathrm{F}_{(19,446)}=1.946, \mathrm{p}>0.05\right)$.

Based on the results, it is concluded that $\mathrm{H1a}$ toH1d are not rejected. Only H1e is rejected showing that there is no significant relationship between number of children and women managers' career development.

Table 12. Pearson product moment correlation between family related barriers and women manager's career development

\begin{tabular}{lcl}
\hline Independent Variable & Pearson Product Moment Correlation Coefficient $(\mathrm{r})$ & $\mathrm{p}$ \\
\hline Family Related Barriers & -.515 & $0.000^{*}$ \\
\hline$*$ Significant at $\mathrm{p}<0.05$ & &
\end{tabular}

Based on the results from Table 12, it shows that $r=-0.515, p<0.05$ indicating that with more responsibilities on family related, there are less chance on their career development.

\section{Discussion and Conclusion}

The objective of this research was to examine the relationship between demographic variables and family related barriers and women managers' career development. The results showed that job level, age, marital status, highest education qualification and family related barriers have significant relationship with women managers' career development. This is consistent with the findings by Levinson (1978) for job level who found that there are different timetables for women in reaching certain level in organization. The finding that age is related to women's career development is consistent with the findings of Levinson (1996) and Roberts and Newton (1987). Levinson (1996) found that women start experiencing the negative effects of glass ceiling at somewhere between the mid to late 30 's. It becomes evident to them that chances for more advancement in their career are progressively being diminished. Whereas, according to Roberts and Newton (1987), women in their 30s find themselves having to make choices between progressing in their career or compromising their career development to take care of their family. There is a relationship between marital status and women's career development. Organization look less favorably on married women when comes to promotion compared to those who are single (Kelly \& Marin, 1998). This could be due to family responsibilities which accompany marriage. As Davidson and Burke (2004) report, combining a family and career can hinder a women's career development. This view was echoed by Broadbridge (2007) who said that responsibility for their household could have negative impact on women's career. This is especially true for married women with children.

There is no significant relationship between number of children and women managers' career development in this study. Majority of the respondents reported that they had the assistance of their husbands, parents, parents-in-law or maids to care for their children. This could be the reason for lack of significant relationship between number of children and their career development.

That educational level has significant influence on women's career development is similar to that reported by Wentling (2003). He found that development of women to top managerial positions depends on their education. Metz (2005) also found that when women increase their education it might help them to break the glass ceiling.

This study found that family related barriers have significance influence on women's career development. 
Women remain the primary caregiver with added responsibility of household organization (Lopez - Claros \& Zahidi, 2005). In households where both husband and wife work, the women still have to take care of the family responsibilities (Budworth, Enns, \& Rowbotham, 2008). These additional responsibilities serve as barriers to career development as women have to divide their energy and effort on managing both their career and family. Marvin (2001) says that women may be at disadvantage in terms of family responsibility where high commitments to organization are expected.

\section{Implication and Recommendation}

Through this research, further implication can be conducted on educational background and career development of working women, their work life balance and also stereotyping and glass ceiling in organizations. Equal opportunities should be given to women in both education and professional development. The way work is organized in the organizations where women work should enable to balance their personal responsibilities with their work responsibilities. The women should be allowed to arrange their work schedule around their family responsibilities. They should also be exposed to examples of women who have been successful in balancing their work with their family.

\section{Limitation and Suggestions for Further Research}

This research was conducted in a single type of organization. Therefore its generalizability is limited. To increase its external validity, the research could be conducted with public sector organizations and private sector organizations. The research could be further enriched using a mixed method where the respondents are given opportunities to voice out their individual problems which the researcher might not have been aware of. Other option is a to conduct a phenomenological study which takes on an inductive grounded theory approach which may provide more specific and detail information on the problem being researched.

\section{References}

Baral, R., \& Bhargava, S. (2010). Work-family enrichment as a mediator between organizational interventions for work-life balance and job outcomes. Journal of Managerial Psychology, 25(3), 274-300. http://dx.doi.org/10.1108/02683941011023749

Broadbridge, A. (2007). Dominated by women: Managed by men? The career development process of retail managers. International Journal of Retail \& Distribution Management, 35(12), 956-974. http://dx.doi.org/10.1108/09590550710835193

Budworth, M., Enns, R., \& Rowbotham, K. (2008). Shared identity and strategic choice in dual career couples. Gender management: An International Journal, 23(2), 103-119. http://dx.doi.org/10.1108/17542410810858312

Catalyst. (2003). Women in Corporate Leadership: Progress \& Prospects.

Chartered Institute of Personnel and Development [CIPD]. (2010). The Talent Perspective: What does it feel like to be talent-managed? London: CIPD.

Davidson, M. J., \& Burke, R. J. (2004). Women in Management Worldwide: Facts, Figures, and Analysis. Ashgate, Aldershot.

Grant Thorton. (2012). Grant Thorton International Business Report. Retrieved from http://www.internationalbusinessreport.com

Harvey, T. R. (2007). Aferican American women's career development: the role of self efficacy as a mediator of leadership aspiration (Doctoral Dissertation). The Pennsylvania State University.

Hoobler, J. M., Wayne, S. J., \& Lemmon, G. (2009). Bosses' perceptions of family-work conflict and women's promotability: Glass ceiling effects. Academy of Management Journal, 52, 939-957. http://dx.doi.org/10.5465/AMJ.2009.44633700

Isabel, M. (2005). Advancing the careers of women with children. Career Development International, 10(3), 228-245. http://dx.doi.org/10.1108/13620430510598346

Javaheri, F., \& Dariapour, Z. (2008). Occupational problems facing female university faculty members. Women in development and politics, 6(2), 79-106.

Kelly, M. R., \& Marin, D. A. J. (1998). Position power and women's career advancement. Women in Management Review, 13(2), 53-66. http://dx.doi.org/10.1108/09649429810208738

Levinson, D. (1978). The seasons of a man's life. New York: Knopf. 
Levinson, D. J. (1996). The seasons of a woman's life. New York: Knopf.

Liff, S., \& Ward, K. (2001). Distorted views through the glass ceiling: The construction of women's' understanding of promotion and senior management positions. Gender, Work and Organisation, 8(1), 19-36. http://dx.doi.org/10.1111/1468-0432.00120

Lirio, P., Lituchy, T. R., Monserrat, S. I., Olivas-Lujan, M. R., Duffy, J., Fox, S., ... Santos, N. (2007). Exploring career-life success and family social support of successful women in Canada, Argentina, and Mexico. Career Development International, 12(1), 28-50. http://dx.doi.org/10.1108/13620430710724811

Lyness, K., \& Heilman, M. (2006). When fit is fundamental: Performance evaluations and promotions of upper-level female and male managers. Journal of Applied Psychology, 91(4), 777-785. http://dx.doi.org/10.1037/0021-9010.91.4.777

Marcinkus, W. C., Berry, K. S. W., \& Gordon, J. R. (2007). The relationship of social support to the work-family balance and work outcomes of midlife women. Women in Management Review, 22(2), 86-111. http://dx.doi.org/10.1108/09649420710732060

Mavin, S. (2001). Women's career in theory and practice: Time for change. Women in Management Review, 16(4), 183-192. http://dx.doi.org/10.1108/09649420110392163

Powell, G. N., \& Graves, L. M. (2003). Women and Men in Management (3rd ed.). Sage, London.

Roberts, P., \& Newton, P. (1987). Levinsonian studies of women's adult development. Psychology and Aging, 2(2), 154-163. http://dx.doi.org/10.1037/0882-7974.2.2.154

Shannon, Y. (2007). The career development of a senior woman athletic administrator (Doctoral Dissertation). North Carolina State University.

Tharenou, P. (1995). Managerial Career Advancement. International Review of Industrial and Organizational Psychology, 12, 39-93.

Tharenou, P. (1997). Managerial career advancement. In C. L. Cooper, \& L. T. Robertson (Eds.), International review of industrial and organizational psychology. New York: Wiley.

Wentling, R. M. (2003). The career development and aspiration of women in middle management-revisited. Women in management review, 18(6), 311-324. http://dx.doi.org/10.1108/09649420310491486

\section{Copyrights}

Copyright for this article is retained by the author(s), with first publication rights granted to the journal.

This is an open-access article distributed under the terms and conditions of the Creative Commons Attribution license (http://creativecommons.org/licenses/by/3.0/). 